\title{
Pengaruh Sistem Pengendalian Intern Pemerintah terhadap Laporan Keuangan Pemerintah Daerah Kabupaten Rote Ndao
}

\author{
Matheus Gratiano Mali \\ Prodi Ilmu Administrasi Negara, Fakultas Ilmu Sosial dan Ilmu Politik \\ Universitas Widya Mataram \\ theogratiano_88@yahoo.com
}

\begin{abstract}
This Research aims to analyze the effect of implementation of Indonesia's Governmental Internal Control System called SPIP (Sistem Pengendalian Intern Pemerintah) based on the COSO Internal Control-fremawork, on the accountability of Local Government Financial Statements in Rote Ndao Distric. This Research aims to described the very potential factors are affecting the implementation of Indonesia's Governmental Internal Control System, that causes desclaimer opinion on local government financial statements In Rote Ndao Distric, from Supreme Audit Board Representatives of East Nusa Tenggara, since 2009 until 2013 and adverse opinion since 2014 until 2017. This is because the quality of the Local Government Financial Statements submitted does not meet the criteria for reliable, relevant, comparable and understandable.

The Method of research uses a type of descriptive with a qualitative approach. Data was collected through interview, documentation and questionnaires. This research was conduct at Departmen Of Financial and Asset Management as report entity, The Inspektorat as Internal Control Apparatus Of Government. Findings of this research show that inhibiting factor in the application of this Government Internal Control System islack of commitment by the Regional Head and Leader of Department, and the lack of readiness of human resources of government apparatus, which needs serious attention both in quantity and quality of human resource management. Based on these findings it is recommended that the head of the government office is expected to increase awareness of the importance of internal control systems. It should also be constructed ongoing monitoring of the implementation of Governmental Internal Control System with enhancements to the audit, review, evaluation and other oversight activities
\end{abstract}

Keywords : Governmental Internal Control System, Accountability Local Government Financial Statements

\section{Pendahuluan}

Penelitian ini membahas tentang kebijakan mengenai Sistem Pengendalian Intern Pemerintah (SPIP) yang diperlukan untuk memberikan keyakinan yang memadai (reasonable assurance) terhadap pencapaian efektivitas dan efisiensi pencapaian tujuan penyelenggaraan pemerintahan negara. Pengendalian intern diharapkan mampu 
menciptakan keandalan pelaporan keuangan, pengamanan aset negara dan ketaatan terhadap peraturan perundang-undangan yang berlaku. Tujuan akhir sistem pengendalian intern ini adalah untuk mencapai efektivitas, efisiensi, transparansi dan akuntabilitas pengelolaan keuangan negara. Sistem Pengendalian Intern Pemerintah adalah sistem pengendalian intern yang diselenggarakan secara menyeluruh di lingkungan pemerintah pusat dan pemerintah daerah yang tertuang dalam Peraturan Pemerintah Nomor 60 Tahun 2008 tentang SPIP, mewajibkan menteri/pimpinan lembaga, gubernur dan bupati/walikota untuk melakukan pengendalian terhadap penyelenggaraan kegiatan pemerintahannya. Terbitnya SPIP juga didorong oleh terjadinya reformasi di bidang keuangan negara yang membawa implikasi perlunya sistem pengelolaan keuangan negara yang lebih akuntabel dan transparan. Berubahnya sistem pengelolaan keuangan negara tidak hanya dalam hal penerapan penganggaran namun juga dalam sistem pencatatan, pertanggungjawaban, dan pengawasan atas akuntabilitas keuangan negara.

Pemeriksaan atas Laporan Keuangan Pemerintah Daerah ditujukan untuk memberikan opini atas kewajaran Laporan Keuangan Pemerintah Daerah dengan memperhatikan kesesuaian Laporan Keuangan dengan Standar Akuntansi Pemerintahan, kecukupan pengungkapan, efektivitas sistem pengendalian intern dan kepatuhan terhadap peraturan perundang-undangan. Opini yang diberikan oleh BPK atas Laporan Keuangan
Pemerintah Daerah (LKPD) TA 2013 pada Kabupaten Rote Ndao adalah Tidak Memberikan Pendapat (Disclaimer of Opinion). Pada TA 2012, Pemerintah Kabupaten Rote Ndao juga memperoleh Opini Tidak Memberikan Pendapat (Disclaimer of Opinion) dengan 7 (tujuh) hal yang menjadi pertimbangan yakni permasalahan terkait Persediaan, permasalahan terkait Investasi Non Permanen Dana Bergulir, Laporan Keuangan Perusahaan Daerah Ita Esa yang belum diaudit oleh Auditor Independen, permasalahan terkait Aset Tetap, terdapat penggunaan langsung pendapatan dari Program Jamkesmas dan Jampersal pada Dinas Kesehatan, terdapat kelebihan pembayaran Belanja Perjalanan Dinas pada Bagian Umum Sekretariat Daerah dan Sekretariat DPRD, terdapat Belanja Sewa Sarana Mobilitas Udara pada Dinas Perhubungan, Komunikasi dan Informatika berupa perjanjian kerja sama dengan PT TAM berindikasi merugikan keuangan negara/daerah serta permasalahan pemutusan kontrak pada Badan Lingkungan Hidup tanpa disertai pengembalian uang muka dan pencairan jaminan pelaksanaan. Serta mendapat Opini Wajar dengan Pengencualian sejak tahun 2014 sampai 2017.

Hal-hal inilah yang masih ditemui pada Sejumlah Entitas atau SKPD pada Kabupaten Rote Ndao yang berdampak terhadap Pernyataan Tidak Memberikan Pendapat atas Laporan Keuangan Pemerintah Daerah oleh BPK, yang sangat membutuhkan perhatian serius untuk ditindak lanjuti demi 
perubahan kearah perbaikan. Dapat terlihat

Disclaimer tersebut.

pada tabel berikut, sejumlah penyebab opini

Tabel 1

Opini BPK terhadap Laporan Keuangan Pemda Rote Ndao

\begin{tabular}{|c|c|c|c|c|}
\hline \multirow{2}{*}{ Tahun } & \multirow{2}{*}{ OPINI } & \multicolumn{2}{|c|}{ Temuan } & \multirow{2}{*}{ Jumlah } \\
\hline & & SPI & Kepatuhan & \\
\hline 1 & 2 & 3 & 4 & 5 \\
\hline 2007 & Disclaimer & 9 & & 9 \\
\hline 2008 & WDP & 3 & 2 & 5 \\
\hline 2009 & Disclaimer & 12 & 11 & 23 \\
\hline 2010 & Disclaimer & 39 & 40 & 79 \\
\hline 2011 & Disclaimer & 35 & 32 & 67 \\
\hline 2012 & Disclaimer & 16 & 24 & 40 \\
\hline 2013 & Disclaimer & 8 & 15 & 23 \\
\hline 2014 & $\begin{array}{c}\text { Wajar Dengan } \\
\text { Pengecualian } \\
\text { (WDP) }\end{array}$ & 3 & 2 & 5 \\
\hline 2015 & $\begin{array}{c}\text { Wajar Dengan } \\
\text { Pengecualian } \\
\text { (WDP) }\end{array}$ & 5 & 9 & 14 \\
\hline 2016 & $\begin{array}{c}\text { Wajar Dengan } \\
\text { Pengecualian } \\
\text { (WDP) }\end{array}$ & 9 & 7 & 16 \\
\hline 2017 & $\begin{array}{c}\text { Wajar Dengan } \\
\text { Pengecualian } \\
\text { (WDP) }\end{array}$ & 7 & 6 & 13 \\
\hline
\end{tabular}

Sumber : Inspektorat Kabupaten Rote Ndao 


\section{Kerangka Teoritik}

Model Internal Control Menurut COSOFramework

COSO merupakan sebuah organisasi independen yang memberikan fokus utamanya terhadap peningkatan kualitas laporan keuangan dengan melakukan serangkaian kegiatan tata kelola usaha yang baik dan pelaksanaan Internal Control yang efektif. Lahirnya COSO erat kaitannya kaitannya perubahan secara besarbesaran yang terjadi sejak adanya regulasi terhadap Internal Controls.

Poin penting dalam report COSO 'Internal Control-Integrated framework' (1992) Definisi internal control menurut COSO, Suatu proses yang dijalankan oleh dewan direksi, manajemen, dan staff, untuk membuat reasonable assurance mengenai, 1).Efektifitas dan efisiensi operasional, 2). Reliabilitas pelaporan keuangan, dan 3). Kepatuhan atas hukum dan peraturan yang berlaku, menurut COSO framework, Internal control terdiri dari 5 komponen yang saling terkait, yaitu:

\section{1) The Control Environment}

Komponen ini merupakan pondasi awal untuk pengembangan Sistem Internal Controls dengan menyediakan disiplin dan struktur yang bersifat fundamental. Hal ini diantaranya mencakup: Integritas dan Nilai Etika, Komitmen terhadap Kompetensi, Berfungsinya Auditor, Filosofi Manajemen dan Gaya Kepemimpinan, Struktur Organisasi, Pemberian Wewenang dan Tanggung Jawab, Kebijakan dan Praktik
Sumber Daya Manusia (SDM). Ketiadaan satu atau lebih unsur yang penting dari lingkungan pengendaliaan akan menyebabkan sistem tidak efektif, meskipun terdapat kekuatan dari sisi empat komponen pengendalian internal yang lain. Efektivitas Internal Controls merupakan fungsi dari unsur lingkungan pengendalain terhadap individual yang menciptakan, mengadministrasikan, dan memonitor pengendalian. Suatu organisasi perlu menetapkan lingkungan pengendalian yang dikomunikasikan kepada pegawai dan diperkuat dalam pelaksanaan kegiatan sehari- hari.

\section{2) Risk Assessment}

Komponen ini merupakan identifikasi dan analisis yang dilakukan oleh manajemen terhadap proses pengendalian menyatu pada tindakan dan kegiatan yang dilakukan secara terus-menerus oleh pimpinan dan seluruh pegawai, maka yang menjadi fondasi dari pengendalian adalah orangorang (SDM) di dalam organisasi yang membentuk lingkungan pengendalian yang baik dalam mencapai sasaran dan tujuan yang ingin dicapai instansi pemerintah. Penilaian risiko organisasi dapat dilakukan melalui identifikasi, analisis, dan pengelolaan risiko-risiko yang relevan terhadap penyusunan laporan keuangan yang secara wajar disajikan sesuai dengan prinsip-prinsip akuntansi berlaku umum.Risiko organisasi dapat berasal dari 
perubahan dalam lingkungan operasi, personil baru, sistem informasi baru, pertumbuhan organisasi yang cepat, teknologi baru, dan lain-lain.

\section{3) Control Activities}

Komponen ini berupa kegiatan, kebijakan, prosedur dan praktek yang menjamin pencapaian tujuan institusi. Kegiatan ini memungkinkan pengambilan berbagai tindakan yang diperlukan untuk mengelola risiko terhadap pencapaian tujuan organisasi. Kegiatan pengendalian berlangsung di seluruh organisasi, semua tingkatan dan pada semua fungsi yang ada. Kegiatan ini mencakup rentang kegiatan mulai dari pengesahan, kewenangan, verifikasi, rekonsiliasi, pengkajian ulang kinerja, pengamanan aktiva dan pemisahan tugas. Kegiatan pengendalian yang dapat dilakukan diantaranya penelahaan kinerja, pengolahan informasi, pengendalian fisik dan pemisahan fungsi.

\section{4) Information and Communication}

Komponen ini mendukung semua komponen pengendalian lainnya dengan mengkomunikasikan tanggung jawab pengendalian kepada seluruh pegawai dan menyediakan informasi dalam sebuah bentuk dan kerangka waktu yang mengizinkan orang menyelesaikan tugasnya. Sistem informasi yang ada menghasilkan laporan-laporan yang berisi informasi mengenai kegiatan organisasi, keuangan dan informasi yang ada hubungannya dengan kepatuhan, yang memungkinkan penggunaannya untuk menjalankan dan mengendalikan organisasi. Informasi ini tidak hanya berhubungan dengan data yang dihasilkan internal, tetapi juga mengenai peristiwa-peristiwa eksternal, kegiatan-kegiatan dan kondisi yang dibutuhkan untuk menginformasikan pengambilan keputusan dan pelaporan untuk pihak luar.

\section{5) Monitoring}

Komponen ini memberikan kepastian yang memadai bahwa tujuan suatu organisasi dapat tercapai, manajemen harus memonitor sistem Internal Controls untuk menentukan apakah sistem beroperasi seperti yang diinginkan dan dimodifikasi agar sesuai dengan perubahan dalam kondisi. Pemantauan merupakan suatu proses yang menilai mutu sistem Internal Controls sepanjang waktu. Pemantauan mencakup personil yang tepat untuk menilai disain dan operasi pengendalian dengan dasar yang tepat waktu dalam mengambil tindakan perbaikan yang diperlukan.

\section{Akuntabilitas Pelaporan Keuangan Pemerintah Daerah}

Govermental Accounting Standart Board (GASB) dalam Concepts Statement No. 1 tentang Objectivitas of Financial Reporting menyatakan bahwa akuntabilitas merupakan dasar dari pelaporan keuangan di pemerintah. 
Terdapat keterkaitan yang jelas antara akuntabilitas dan pelaporan keuangan pemerintah.

Pengawasan dan pengendalian dalam pengelolaan anggaran daerah pada dasarnya dimaksudkan agar setiap dana yang dibelanjakan oleh pemerintah daerah berdampak terhadap kepentingan dan kebutuhan publik serta dapat dipertanggungjawabkan kepada publik. Artinya bahwa APBD harus mencerminkan kebutuhan riil masyarakat daerah. Salah satu wujud akuntabilitas dan transparansi dalam pengelolaan pembangunan dan keuangan derah adalah dengan mewajibkan Kepala Daerah untuk mempertanggungjawabkan pelaksanaan pembangunan dan pemerintahan didaerahnya pada setiap akhir tahun anggaran. Selain itu, dalam pengelolaan anggaran daerah telah terjadi perubahan pendekatan yang harus lebih menekankan pada pentingnnya aspek kinerja (performance).

Secara karakteristik, tujuan dari pelaporan keuangan yang diwujudkan dalam informasi akuntansi yang merupakan prasyarat normatif agar laporan keuangan harus memenuhi kualitas yang diingankan yaitu:
a) Laporan keuangan harus mempunyai informasi yang relevan, yakni;
b) Laporan keuangan harus mempunyai informasi yang dapat dibandingkan.
c) Laporan keuangan harus dapat dipahami.

\section{Metode penelitian}

Pada penelitian ini, jenis penelitian yang digunakan adalah penelitian kualitataif. Menurut Sugiyono (2013) penelitian kualitatif adalah peneltian yang digunakan untuk meneliti pada kondisi obyek yang alamiah, (sebagai lawannya adalah eksperimen) dimana peneltiti adalah sebagai instrument kunci, teknik pengumpulan datadilakukan secara trianggulasi (gabungan), analisis data bersifat induktif dan hasil penelitian kualitatif lebih menekankan pada makna daripada generalisasi.

Kriteria dalam penelitian kualitatif adalah data yang pasti. Data yang pasti adalah data yang sebenarnya terjadi sebagaimana adanya, bukan data yang sekedar terlihat, terucap, tetapi data yang mengandung makna di balik yang terlihat dan terucap tersebut.

\section{Pembahasan}

\section{Penerapan Unsur-Unsur Sistem Pengendalian}

\section{Intern Pemerintah di Kabupaten Rote Ndao}

\section{A. Lingkungan Pengendalian}

Lingkungan pengendalian merupakan pondasi dari sistem pengendalian yang dibentuk oleh perilaku orang-orang di dalam organisasi dalam mencapai tujuan organisasi. Lingkungan pengendalian berperan sangat penting dalam rangka meningkatkan kepedulian dan keikutsertaan seluruh pegawai serta menjadi komitmen bersama dalam melaksanakannya untuk mendukung terselenggaranya unsur-unsur SPIP 
lainnya. Temuan pada Pemerintah Kabupaten Rote Ndao bahwa unsur ini belum diterapkan dengan optimal terlihat dari belum terlaksana dengan konsisten kegiatan penegakan nilai dan etika dalam pelaksanaan setiap tugas oleh aparat pemerintah, belum terbangunnya komitmen terhadap kompetensi khususnya jabatan yang berhubungan dengan pengelolaan keuangan, belum dibangun secara nyata kepemimpin yang kondusif untuk membangun suasana kerja, serta belum optimalnya kegiatan pengendalian dalam perwujudan peran Aparat Pengawasan Internal Pemerintah (APIP) untuk terus mendorong pelaksanaan SPIP secara berkelanjutan untuk mendorong berhasilnya penerapan SPIP dan sejumlah tugas lainnya,

\section{1) Penilaian Resiko}

Berdasarkan hasil monitoring atas pelaksanaan SPIP di Kabupaten Rote Ndao yang telah dilakukan Diagnostic Assessment oleh BPKP RI Perwakilan NTT sejak tahun 2013. Penerapan SPIP berupa perbaikan pada unsur Penilaian Resiko adalah belum dibuatnya Kebijakan Identifikasi dan Analisis Resiko. Penetapan maksud dan tujuan instansi pemerintah yang jelas dan konsisten, baik pada tingkat instansi maupun pada tingkat kegiatan. Selanjutnya, instansi pemerintah harus mengidentifikasi secara efisien dan efektif risiko yang dapat menghambat pencapaian tujuan tersebut, baik yang bersumber dari dalam maupun luar instansi. Beberapa kegiatan terlihat bahwa pemerintah Rote Ndao belum melakukan identifikasi dan analisis resiko contoh identifikasi resiko ketidaklancaran pelunasan pajak, retribusi dan piutang daerah belum dibuat, identifikasi resiko temuan yang sulit tertagih belum dilakukan, identifikasi resiko penyertaan modal kepada PDAM dan PD. Ita Esa belum didokumentasikan dengan baik.

\section{2) Kegiatan Pengendalian}

Kegiatan pengendalian merupakan serangkaian kegiatan yang bersifat detektif dan preventif yang diperlukan untuk mengatasi resiko, penetapan dan pelaksanaan kebijakan serta prosedur. Selain itu tindakan pengendalian juga bertujuan untuk memastikan bahwa tindakan mengatasi resiko telah dilaksanakan secara efektif. Hasil penelitian ada unsur kegiatan pengedalian bahwa, Pemda Rote Ndao maupun SKPD belum memiliki strategi pembinaan sumberdaya manusia dalam bentuk rencana kerja tahunan dan dokumen perencanaan sumberdaya manusia lainnya, yang meliputi kebijakan, program, dan praktik pengelolaan pegawai yang akan menjadi panduan bagi instansi pemerintah tersebut secara jelas, seperti 
ditemui dilapangan bahwa aparat pemerintah ataupun staf yang diikut sertakan dalam diklat ataupun bimtek hanyalah untuk memenuhi penggunaan dana dalam DPA yang dianggarkan dalam APBD. Belum ada kebijakan pengendalian atas peralatan yang beresiko dicuri, kebijakan pengendalian fisik dan melindungi dari kerusakan, kebijakan pengendalian aset dari bahaya kebakaran dan kebijakan pengendalian berupa pembatasan akses ke gedung dan fasilitas. Kemudian aset-aset tetap tidak disajikan berdasarkan verifikasi, rekonsiliasi dan inventarisasi yang memadai, selain itu belanja perencanaan dan pengawasan belum didistribusikan ke tiap aset tetap, dan belum dirincikan aset tetap peralatan mesin serta aset tetap lainnya.

\section{a) Informasi dan Komunikasi}

Berdasarkan hasil wawancara bahwa pimpinan instansi pemerintah belum menerima informasi hasil analisis yang dapat membantu dalam mengidentifikasi tindakan khusus yang perlu dilaksanakan informasi belum disiapkan dalam bentuk rincian yang tepat sesuai dengan tingkatan pimpinan instansi pemerintah., informasi belum secara relevan diringkas dan disajikan secara memadai sehingga belum memungkinkan dilakukan pengecekan secara rinci sesuai dengan keperluan. Sering terjadi keterlamabatan dalam penyapaian informasi keuangan dan anggaran yang memadai sudah disediakan sehingga belum mendukung penyusunan pelaporan keuangan internal dan eksternal. Contoh temuan adalah Pengelola Keuangan SKPD belum sepenuhnya memperoleh informasi yang memadai mengenai pengelolaan piutang pajak daerah dan retribusi daerah dari Bendahara Umum Daerah (BUD), sehingga penyajian Laporan Keuangan SKPD khususnya Piutang pada SKPD tidak sama dengan pencatatan Piutang pada BUD walaupun sudah ada manajemen sistem informasi dilaksanakan berdasarkan suatu rencana strategis sistem informasi yang merupakan bagian dari rencana strategis instansi pemerintah secara keseluruhan berupa SIMDA akan tetapi pimpinan instansi pemerintah belum secara terus menerus memantau mutu informasi yang dikelola, diukur dari segi kelayakan isi, ketepatan waktu, keakuratan, dan kemudahan aksesnya. Terlihat dari belum optimalnya dukungan pimpinan instansi pemerintah terhadap pengembangan teknologi informasi ditunjukkan dengan komitmennya dalam menyediakan pegawai dan pendanaan yang memadai terhadap upaya pengembangan tersebut. Hasil temuan BPK juga menggambarkan bahwa komunikasi antar pengelola keuangan SKPD dengan BUD tidak optimal 
sehingga fungsi dan peran Pengelola Keuangan SKPD tidak dilaksanakan secara baik, dan komunikasi antar pengelola pajak, retribusi dan piutang dengan BUD belum optimal.

\section{b) Pemantuan}

Hal penting lainnya yang ditemui dilapangan adalah pimpinan instansi pemerintah belum dan sering terlambat mengambil langkah untuk menindaklanjuti rekomendasi penyempurnaan pengendalian internal yang secara teratur diberikan oleh aparat pengawasan intern pemerintah dalam hal ini adalah Inspektorat, auditor, dan evaluator lainnya, contohnya Evaluasi terhadap pencapaian target penerimaan daerah dari pajak, retribusi dan piutang belum dilakukan

\section{B. Faktor-Faktor Penyebab Opini Discalimer dan Wajar Dengan Pengecualian (WDP) Atas Laporan Keuangan Pemerintah Daerah Kabupaten Rote Ndao}

\section{1) Laporan Hasil Pemeriksaan atas Laporan Keuangan Pemerintah Kabupaten Rote Ndao Tahun Anggaran 2013 -2017}

Berdasarkan hasil wawancara dan penelusuran terhadap hasil pemeriksaan atas Laporan Keuangan Pemerintah
Kabupaten Rote Ndao, berikut diungkapkan ringkasan hal-hal yang menjadi faktor penyebab opini Disclaimer :

a) Pemerintah Kabupaten Rote Ndao menyajikan $\underline{\text { Kas }}$ di Bendahara Pengeluaran. Nilai tersebut belum termasuk saldo di Dinas PPKAD. Hal ini tidak sesuai dengan prinsip substansi mengungguli bentuk formal dalam Standar Akuntansi Pemerintahan, dimana transaksi atau peristiwa lain tersebut perlu dicatat dan disajikan sesuai dengan substansi dan realitas ekonomi, dan bukan hanya aspek formalitas.

b) Pemerintah Kabupaten Rote Ndao menyajikan Kas lainnya di Bendahara Pengeluaran Sekretariat DPRD belum disetorkan ke Kas Daerah dan Bendahara Pengeluaran tidak dapat menunjukan sisa uang tersebut.

c) Pemerintah Kabupaten Rote Ndao menyajikan Persediaan pada Dinas Pertanian, Perkebunan dan Kehutanan, belum dicatat dengan hasil memadai serta belum seluruh saldo persediaan disajikan berdasarkan penyesuaian catatan dengan hasil perhitungan fisik persediaan pada akhir tahun. Catatan-catatan dan dokumen yang tersedia tidak memungkinkan BPK 
untuk melakukan prosedur pemeriksaan yang memadai untuk meyakini nilai persediaan tersebut.

d) Pemerintah Kabupaten Rote Ndao menyajikan Investasi Non Permanen Dana Bergulir yang belum disajikan berdasarkan hasil inventarisasi secara memadai dan belum didukung dengan surat Perjanjian/Kontrak Investasi Non Permanen Dana Bergulir dan atas penghapusan yang dilaksanakan tidak berdasarkan data dasar yang valid sebagai dasar penghapusan.

e) Pemerintah Kabupaten Rote Ndao menyajikan Investasi Permanen berupa investasi penyertaan modal pada PD Ita Esa tidak disajikan berdasarkan Laporan Keuangan yang telah diaudit oleh Auditor Independen.

f) Pemerintah Kabupaten Rote Ndao menyajikan Kewajiban Dalam Nilai tersebut belum termasuk Utang Belanja kepada pihak ketiga. Selain itu Pemerintah Kabupaten Rote Ndao belum menindaklanjuti hasil pemeriksaan BPK RI menelusuri saldo awal atas Kewajiban minimal berupa pungutan pajak yang ditampung sebelum disetorkan ke Kas Negara dalam rekening titipan pajak. Atas pengelolaan rekening tersebut terdapat selisih penyetoran pajak dan jasa giro dari rekening penampungan pajak belum disetorkan ke Kas Daerah.

g) Pemerintah Kabupaten Rote Ndao menyajikan Belanja Barang Realisasi Belanja Barang dan Jasa sebesar tidak didukung dengan bukti pertanggungjawaban yang riil dan lengkap.

\section{Opini yang diberikan oleh BPK atas Laporan} Keuangan Pemerintah Daerah (LKPD) TA 2014 pada Kabupaten Rote Ndao adalah Wajar Dengan Pengecualian. Terdapat peningkatan opini, jika dibandingkan dengan Opini LKPD TA 2013 yaitu Tidak Memberikan Pendapat karena 8 (delapan) permasalahan terkait akun: (1) Kas di Bendahara Pengeluaran; (2) Kas Lainnya di Bendahara Pengeluaran; (3) Persediaan; (4) Investasi Permanen; (5) Investasi Non Permanen; (6) Aset Tetap; (7) Utang Belanja; dan (8) Belanja Barang. Pemerintah Daerah telah melakukan perbaikan pengelolaan atas Kas di Bendahara Pengeluaran dan Kas Lainnya di Bendahara Pengeluaran, sehingga masih terdapat 6 (enam) hal yang menjadi pertimbangan penilaian kewajaran Laporan Keuangan TA 2014, yaitu sebagai berikut:

1. Nilai Persediaan belum seluruhnya disajikan berdasarkan penyesuaian catatan dengan hasil penghitungan fisik persediaan pada akhir tahun. 
2. Saldo Dana Bergulir belum disajikan berdasarkan hasil inventarisasi secara memadai dan belum disajikan berdasarkan nilai bersih yang dapat direalisasikan (net realizable value), sehingga tidak sesuai dengan Standar Akuntansi Pemerintahan;

3. Nilai Investasi Permanen penyertaan modal pada PD Ita Esa belum disajikan berdasarkan Laporan Keuangan yang telah diaudit oleh Auditor Independen.

4. Terdapat Aset Tetap Tanah dan Peralatan dan Mesin serta Aset Tetap dan Aset Tetap dengan kondisi rusak dan tidak diketahui keberadaannya pada enam SKPD. Terdapat 291 bidang tanah belum dapat dibuktikan dokumen kepemilikannya. Selain itu, nilai Aset Tetap tersebut belum didukung dengan proses inventarisasi yang memadai secara menyeluruh dan reklasifikasi atas barang rusak/tidak digunakan ke Aset Lainnya belum berdasarkan Berita Acara Pemeriksaan Barang.

5. Saldo Kewajiban Jangka Pendek per 31 Desember 2014 disajikan belum termasuk Utang PFK atas pungutan PPh dan PPN yang belum disetorkan ke Kas Negara oleh Bendahara Pengeluaran Dinas PPKAD. Selain itu Pemerintah Kabupaten Rote Ndao belum menindaklanjuti hasil pemeriksaan BPK RI untuk menelusuri saldo awal atas Kewajiban minimal berupa pungutan pajak yang ditampung sebelum disetorkan ke Kas Negara dalam rekening titipan pajak.

6. Realisasi atas pembayaran honorarium/insentif pemungutan pajak, pemungutan retribusi, insentif $\mathrm{PBB}$ dan insentif atas pelampauan target PBB TA 2013 yang belum dibayarkan kepada yang berhak dan Bendahara Pengeluaran tidak mempertanggungjawabkan atas dana tersebut. Hal ini tidak sesuai dengan prinsip substansi mengungguli bentuk formal dalam Standar Akuntansi Pemerintahan.

Kelemahan dalam Sistem Pengendalian Intern pada Pemerintah Kabupaten Rote Ndao antara lain yaitu:

1. Pengelolaan dan penyajian nilai investasi non permanen atas dana bergulir belum memadai;

2. Penatausahaan persediaan di lingkup Pemerintah Kabupaten Rote Ndao belum sepenuhnya memadai; dan

3. Pengelolaan dan penatausahaan Aset Tetap belum sepenuhnya memadai dan disajikan secara akurat dalam Daftar Barang Milik Daerah.

Opini BPK Atas Laporan Keuangan Pemerintah Kabupaten Rote Ndao TA 2015, BPK memberikan opini Wajar Dengan Pengecualian (WDP), dengan hal yang dikecualikan sebagai berikut:

1. Persediaan, belum seluruhnya disajikan dalam Neraca; 
2. Investasi Non Permanen, saldo Dana Bergulir belum sepenuhnya disajikan berdasarkan hasil inventarisasi sehingga penyajiannya tidak akurat;

3. Investasi Permanen, penyertaan modal pada PD Ita Esa tidak disajikan berdasarkan Laporan Keuangan yang telah diaudit oleh Auditor Independen;

4. Aset Tetap, antara lain pengelolaan dan pencatatanaset tetap tanah belum memadai, belum pernah dilakukan sensus Barang Milik Daerah, serta usulan penghapusan aset yang rusak belum ditindaklanjuti;

5. Kewajiban Jangka Pendek, antara lain nilai tersebut belum termasuk Utang PFK atas pungutan PPh dan PPN yang belum disetorkan ke Kas Negara dan terdapat selisih penyetoran pajak.;

6. Penerimaan dan Pengeluaran dari Bantuan Operasional Sekolah(BOS)belum disajikan dan diungkapkan dalam laporan keuangan.

\section{Atas Laporan Keuangan Pemerintah}

Kabupaten Rote Ndao TA 2017, BPK memberikan opini Wajar Dengan Pengecualian (WDP), dengan hal yang dikecualikan yaitu:

1) Belanja dan Pembiayaan - Terdapat realisasi Belanja Pegawai serta Pengeluaran yang anggarannya tidak ditetapkan dalam Perda APBD, yang menunjukkan ketidakpatuhan terhadap peraturan perundang-undangan.

2) Aset Tetap - Terdapat kelemahan pengendalian intern yang signifikan atas pencatatandan penyajian Aset Tetap, yaitu (1) inventarisasi aset tetap belum dilakukan pada seluruh OPD; (2) Aset Tetap dalam Neraca belum menggambarkan nilai dan kondisi yang sebenarnya, di antaranya tanah di bawah jalan belum diinventarisasi dan dicatat, tanah dibawah ruas jaringan dan daerah irigasi belum seluruhnya dicatat dan belum diinventarisasi, terdapat 16 bidang tanah idak diketahui luasan tanahnya.

\section{i. Kelemahan Dalam Penerapan Sistem Pengendalian Intern}

1. Penatausahaan Pengeluaran Kas dan Pengendalian Sisa Kas di Bendahara Pengeluaran belum dilaksanakan secara memadai.

2. Pentatausahaan Persediaan Pada Empat SKPD Di Lingkup Kabupaten Rote Ndao, Nilai persediaan yang tersaji di empat SKPD belum diyakini telah disajikan secara lengkap.

3. Pengelolaan Piutang di kabupaten Rote Ndao belum memadai.

4. Dana bergulir belum diinventaris secara memadai dana atas penghapusan dana bergulir tidak berdasarkan data dasar yang valid. Berdasarkan penghapusan secara 
bersyarat atas Piutang Daerah yang bersumber dari dana Bergulir berklasifikasi penerima Dana Bergulir meninggal dunia, alamat tidak ditemukan lagi dan atau usaha yang tidak berjalan lagi, serta ternak yang telah mati.

5. Pengelolaan Dan Penatausahaan Aset Tetap Kabupaten Rote Ndao Belum Sepenuhnya Memadai Dan Daftar Inventaris Barang Milik Daerah Belum Disajikan Secara Akurat Sebagai Pendukung Data Di Neraca.

6. Sistem Pengelolaan Keuangan Berbasis Teknologi Informasi Belum Optimal Dalam Mendukung Penyusunan Laporan Keuangan Pemerintah Daerah. Pemerintah Kabupaten Rote Ndao Belum secara optimal memanfaatkan penggunaan Teknologi Informasi dalam melakukan tata kelola dan penatausahaan keuangan daerah.

\subsection{Kelemahan Atas Kepatuhan Terhadap} Peraturan Perundang-Undangan

1. Penatausahaan Pengeluaran Kas pada Dinas PPKAD dan Sekretariat DPRD Kabupaten Rote Ndao Tidak sesuai ketentuan.

2. Penyajian Saldo Penyertaan Modal padaPD Ita Esa dalam Neraca tidak berdasarkan Laporan Keuangan yang telah diaudit oleh Auditor Independen.

3. Hibah Aset Tanah Pemerintah Kabupaten Rote Ndao tidak sesuai ketentuan.

4. Mekanisme Pencairan BANSOS Berupa Beasiswa Belum Memadai Dan Penerima Bantuan Belum Menyampaikan Laporan
Pertanggungjawaban Penggunaan Dana, Serta Terdapat Dana Bantuan Yang Belum Diserahkan Kepada Penerima Bantuan.

5. Pemberian Belanja Beasiswa Pendidikan PNS Diberikan Kepada Bukan PNS Dan Sisa Dana Yang Belum Disalurkan Belum Disetor Ke Kas Daerah.

6. Pertanggungjawaban Perjalanan Dinas Luar Daerah Belum Memadai Dan Berindikasi Merugikan Keuangan Daerah.

\section{Kesimpulan}

Berdasarkan hasil penelitian dan pembahasan Analisis Akuntabilitas Laporan Keuangan Dan Kinerja Pemerintah Daerah Kabupaten Rote Ndao Pasca Penerapan Kebijakan Sitem Pengendalian Intern Pemerintah Berdasarkan COSO Internal Control - Framework, dapat ditarik kesimpulan sebagai berikut :

1. Hasil analisis deskriptif menunjukan bahwa secara umum penerapan Sistem Pengendalian Intern Pemerintah di Kabupaten Rote Ndao belum berjalan dengan optimal sesuai yang diamanatkan dalam peraturan Pemerintah Nomor 60 tahun 2008. Hal tersebut terlihat dari belum terlaksananya seluruh unsur dan sub unsur dalam pedoman SPIP itu sendiri. Kelemahan pada pada unsur Lingkungan Pengendalian adalah belum secara konsisten dibungan secara nyata komitmen untuk penegakan disiplin untuk 
membangun suasana yang kondusif untuk penerapan SPIP, kemudian belum adanya kebijakan identifikasi dan analisis resiko sebagai bentuk dari penilaian resiko menyebabkan banyak kerugian dan berpotensi menyebabkan kerugian daerah, dan belum optimalnya kegiatan pengendalian dalam perwujudan peran APIP untuk terus mendorong pelaksanaan SPIP, belum mampu mencegah korupsi dan dan belum mampu memberikan keyakinan atas efisiensi dan efektivitas program/kegiatan Pemerintah Kabupaten Rote Ndao

2. Berdasarkan OPINI BPK dengan temuan berulang pada Dignostic assessment dan temuan dilapangan pada sejumlah SKPD bahwa lemahnya penerapan unsur-unsur SPIP ini menyebabkan : a). laporan keuangan yang tidak dapat dipertangungjawabkan secara wajar, handal, relevan, dan tidak dapat dibandiangkan karena tidak dapat dipahami, b). Banyak aset daerah yang tidak diketahui keberadaannya secara jelas sehingga menyebabkan kerugian daerah dan potensi kerugian daerah, walaupun dalam laporan keuangan sudah disajikan jenis-jenis aset tetap tetapi tidak berdasarkan verifikasi , rekonsiliasi dan inventarisasi yang memadai. Selain itu juga terdapat sejumlah aset daerah yang telah berganti kepemilikannya tetapi tidak disertai bukti kepemilikan, c). Belum efektif dan efisiennya pelaksanaan tugas-tugas aparatur daerah telihat dari pemasalahan rasio penggunaan kuantitas atau kualitas input untuk satu satuan output yang lebih besar yang seharusnya, dan ketidak tercapaian target yang ditetapkan dan penggunaan anggaran yang tidak sesauai rencana dan peruntukan, barang yang dan jasa tidak berdampak pada tujuan organsasi.

3. Faktor - faktor penghambat penerapan SPIP

\section{a) Komitmen Pimpinan}

Hambatan-hambatan dalam penerapan SPIP ini disebabkan karena belum dibangun secara nyata oleh Kepala Daerah maupun Pimpinan SKPD berupa untuk membangun dan memelihara suatu kondisi yang menimbulkan perilaku positif dan kondusif untuk penerapan SPIP di lingkungan kerja masing-masing. Kebijakan-kebijakan yang dihasilkan masih belum diarahkan untuk mendesain secara tepat bagaimana melakukan langkah nyata dalam membangun komitmen tersebut. Dilain sisi pelaksanaan mutasi, promosi dan demosi antar unit kerja dan jabatan belum diatur dalam kebijakan dan prosedur yang mempertimbangkan kompetensi pegawai. Mutasi pegawai belum didasari pertimbangan untuk menambah kompetensi 
sekaligus pengalaman sehingga pegawai belum mempunyai bekal kompetensi mendalam dalam menduduki sebuah jabatan baru. Pelaksanan mutasi, promosi dan demosi belum didasari pada kompetensi yang terdiri dari elemen knowledge, skill, dan attitude.

\section{b) Sumberdaya manusia}

Kesiapan sumber daya manusia yang menjalankan SPIP di bidang akuntabilitas laporan keuangan masih sangat kurang, baik secara kualitas maupun kuantitas. Sistem perekrutan dan penempatan pegawai pada bidang keuangan dan pelaporan menjadi permasalahan, karena bukan berdasarkan kompetensi dan latar belakang pendidikan yang dimiliki dalam bidang akuntansi dan pengelolaan keuangan. Kesiapan SDM aparat pemerintahan membutuhkan perhatian yang lebih serius dan perlu revolusi dalam jumlah dan mutu SDM pengelola keuangan daerah untuk mewujudkan tata kelola keuangan pemerintah daerah yang lebih akuntabel dan transparan.

\section{Daftar pustaka}

Dunn, William N.1998, Pengantar Analisis Kebijakan Publik, Penyunting Muhadjir Darwin. Edisi Kedua.
Cetakan Pertama. Yogyakarta: Gadjah Mada University Press. Fadzil.F.H,Haron.H.2005. Internal Auditing Practices And Internal Control System Managerial Auditing Journal;20, 8/9; ABI/INFORM Complete pg. 844

Halim. 2002. Bunga Rampai Manajemen Keuangan Daerah. Edisi Pertama. Yogyakarta: UPP AMP YKPN.

Mardiasmo. (2004). Membangun Akuntabilitas Publik Keuangan Negara. Media Akuntansi 39/April/Tahun XI/2004, Hal 12.

Moleong, Lexy. 2002. Metodologi Penelitian Kualitatif. Bandung: PT. remaja Rosdakarya.

Muchsan, S.H. 2000. "Sistem Pengawasan Terhadap Perbuatan Aparat Pemerintah Dan Peradilan Tata Usaha Negara DiIndonesia”, Liberty, Yogyakarta.

Yahya, Idhar, 2006. Akuntabilitas dan Transparansi Pengelolaan Keuangan Daerah, Jurnal Sistem Teknik Industri Vol. 7 No. 4 Oktober 2006. Medan, Universitas Sumatera Utara. http://www.usu.ac.id/jurnal-STI.php.

Terpublikasi

\section{Peraturan-Peraturan :}

- Undang-undang Nomor 15 Tahun 2004 tentang Pemeriksanaan Pengelolaan dan Tanggungjawab Keuangan Negara. 
Volume 7, Nomer 1, Januari 2019

- Peraturan Pemerintah Republik Indonesia

\section{Laporan-Laporan :}

Nomor 79 Tahun 2005 Tentang Pedoman

Pembinaan Dan Pengawasan

Penyelenggaraan Pemerintahan Daerah

- Peraturan Pemerintah RI Nomor 60 Tahun

- Siaran Pers Opini BPK tentang LKPD Kabupaten Rote Ndao Ta.2013 - 2017

- Laporan Keuangan Pemerintah Daerah Kabupaten Rote Ndao Ta.2013 - 2017

2008 tentang Sistem Pengendalian Intern Pemerintah.

- $\quad$ Peraturan Menteri Dalam Negeri Nomor 13

Tahun 2006 tentang Pedoman Pengelolaan Keuangan Daerah.

- Pedoman Teknis Penyelenggaraan SPIP oleh BPKP RI 